\title{
GROWTH, ENZYMATIC ACTIVITY, AND ANTIOXIDANT ACTIVITY OF SWEET BASIL GROWN IN VITRO ${ }^{1}$
}

\author{
VANESSA FERNANDES FONSECA WELZ ${ }^{2}$, JÉSSICA REZENDE TRETTEL ${ }^{2}$, ANDRESSA BEZERRA \\ NASCIMENTO $^{3}$, HÉLIDA MARA MAGALHÃES $^{2 *}$
}

\begin{abstract}
Sweet basil is a perennial herb. Studies on in vitro cultivation of these plant species are scarce and inconclusive. This study was carried out to investigate the effect of culture medium concentration in combination with antioxidants and plant growth regulators on the in vitro growth and biochemical activity of sweet basil seedlings. Seeds of the 'Genovese' cultivar were inoculated into Murashige and Skoog culture medium supplemented with activated carbon and plant growth regulators 6-benzylaminopurine and $\alpha$ naphthaleneacetic acid. The seedlings were grown under controlled conditions for 80 days and their biometric and biochemical characteristics evaluated. More abnormal seedlings were observed in the $100 \%$ medium with $30 \mathrm{~g} \mathrm{~L}^{-1}$ sucrose, $0.4 \mathrm{~g} \mathrm{~L}^{-1}$ 6-benzylaminopurine, and $0.2 \mathrm{~g} \mathrm{~L}^{-1} \alpha$-naphthaleneacetic acid (T4) and the medium without regulators (T1). However, the T4 culture medium resulted in a higher leaf number and shoot dry mass. Antioxidant activity was higher in the seedlings grown in the culture medium composed of $100 \%$ medium +3.0 $\mathrm{g} \mathrm{L}^{-1}$ activated carbon $+0.4 \mathrm{mg} \mathrm{L}^{-1}$ 6-benzylaminopurine $+0.2 \mathrm{mg} \mathrm{L}^{-1} \alpha$-naphthaleneacetic acid (T5) and that composed of $70 \%$ medium $+3.0 \mathrm{~g} \mathrm{~L}^{-1}$ activated carbon $+0.1 \mathrm{mg} \mathrm{L}^{-1} 6$-benzylaminopurine (T3). The enzyme superoxide dismutase showed higher activity in all culture media than catalase or ascorbate peroxidase. Sweet basil seedlings growing in T4 and T1 medium showed the highest growth rate of shoots and the lowest antioxidant activity, whereas seedlings grown in T3 medium had the highest catalase and ascorbate peroxidase activity.
\end{abstract}

keywords: Enzymes. Lamiaceae. Micropropagation. Ocimum basilicum L. 'Genovese'.

\section{CRESCIMENTO, ATIVIDADE ENZIMÁTICA E ANTIOXIDANTE DE MANJERICÃO CULTIVADO IN VITRO}

\begin{abstract}
RESUMO - O manjericão é uma erva perene. Objetivou-se com essa pesquisa avaliar a influência da concentração do meio de cultura associado a antioxidantes e reguladores de crescimento sobre o crescimento e atividade bioquímica de plântulas de manjericão cultivadas in vitro. Sementes da cultivar genovese foram inoculadas em meio Murashige e Skoog - MS suplementado com carvão ativado e reguladores de crescimento benzilamonopurina e ácido naftalenoacético. As plântulas cresceram em condições controladas durante 80 dias e após este período avaliou-se características biométricas e bioquímicas. Maior quantidade de plântulas anormais foi verificada no meio composto por MS 100\%, sacarose $30 \mathrm{gL}^{-1}$, BAP $0,4 \mathrm{gL}^{-1}$ e ANA $0,2 \mathrm{gL}^{-1}$ (T4) e (T1) sem reguladores. No entanto, esse mesmo tratamento incrementou o número de folhas, e massa e fresca seca das brotações. A atividade antioxidante foi maior nas plântulas que foram mantidas no T5 - 100\% MS, carvão ativado $3,0 \mathrm{gL}^{-1}+0,4 \mathrm{mgL}^{-1} \mathrm{BAP}+0,2 \mathrm{mgL}^{-1} \mathrm{ANA}$ e no T3 - 70\% $\mathrm{MS}$, carvão ativado $3,0 \mathrm{gL}^{-1}+$ $0,1 \mathrm{mgL}^{-1}$ BAP. A análise enzimática revelou que a enzima superóxido dismutase apresentou maior atividade em todos os tratamentos quando comparada com a catalase e a ascorbato peroxidase. Sendo assim, as plântulas de manjericão genovese que cresceram no T4 e T1 apresentaram melhores médias de crescimento em folhas e menor atividade antioxidante. Já as plântulas que cresceram no T3 apresentaram médias maiores para as enzimas catalase e ascorbato peroxidase.
\end{abstract}

Palavras-chave: Enzimas. Lamiaceae. Microporpagação. Ocimum basilicum L. 'Genovese'.

\footnotetext{
${ }^{*}$ Corresponding author

${ }^{1}$ Received for publication in $09 / 11 / 2019$; accepted in 05/07/2020.

Paper extracted from the master's thesis of the first author.

${ }^{2}$ Postgraduate Programs in Biotechnology Applied to Agriculture, Universidade Paranaense, Umuarama, PR, Brazil; vanessaferfonseca@gmail.com - ORCID: 0000-0002-3852-5094, jrtrettel@gmail.com - ORCID: 0000-0003-0904-829X, helidamara@prof.unipar.br-ORCID: 0000-0002-0402-7716.

${ }^{3}$ Graduate Agronomy, Universidade Paranaense, Umuarama, PR, Brazil; andressa.bnascimento@hotmail.com - ORCID: 0000-0002-53270368 .
} 


\section{INTRODUCTION}

Sweet basil or 'Genovese' basil is the common name of the species Ocimum basilicum L. (family Lamiaceae), which is a perennial herb native to the tropical and sub-tropical regions of the world (LIBER et al., 2011). It has been used in cuisines worldwide as a condiment and in the preparation of sauces. However, it is also used for the extraction of its essential oil, which contains high levels of natural compounds, such as phenylpropanoids and terpenoids (FLANIGAN; NIEMEYER, 2014; AMARAL-BAROLI et al., 2016). Basil essential oil has been widely used in the pharmaceutical, cosmetic, and toiletry industries because of the antioxidant, antitumor, and antimicrobial capacity of its chemical compounds (FLANIGAN; NIEMEYER, 2014; TENORE et al., 2017). Currently, the essential oil is extracted from the leaves, which have glands capable of producing and storing these compounds (ZUZARTE et al., 2010; AMARAL-BAROLI et al., 2016).

Sweet basil is usually grown in the field, and its leaves are marketed to industries that extract their oil (LIBER et al., 2011). The main limiting factor of this cultivation method is that chemical compounds can be altered by the climatic and biotic conditions of the environment. This promotes heterogeneity in the plant's chemical composition that is not appreciated by the industry (TRETTEL et al., 2018b). A method to standardize the production of these chemical compounds can be obtained through plant tissue culture techniques (ALVAREZ, 2014). The advantage of using this cultivation technique is that the seedlings grow under controlled conditions, such as the culture medium and temperature (WEATHERS; TOWLER; XU, 2010). Thus, the chemical composition of the oil is more homogeneous and predictable; moreover, the plant's metabolism can be directed toward the production of chemical compounds of greater industrial interest (ALVAREZ, 2014).

Murashige and Skoog (MS) medium has been the main culture medium used in the culture of medicinal plants (SILVA et al., 2017; TRETTEL et al., 2017; TRETTEL et al., 2018b). However, as specific nutritional requirements can enhance explant growth, adjustments are needed to promote a better cost-benefit ratio for seedling growth (SILVA et al., 2017). In recent years, some researchers have focused their studies on the establishment of in vitro culture protocols for medicinal plants. Nevertheless, many questions remain to be elucidated. For example, the characteristics of the culture medium should be standardized for different cultivars. The genus Ocimum contains numerous cultivars (MAROTTI; PICCAGLIA; GIOVANELLI, 1996), so the use of a single culture medium composition should not be recommended. Many physiological and morphological responses observed under in vitro growth, such as callus formation, adventitious root emission, and shoot emission, remain unknown in the genus Ocimum, especially with regard to culture medium formulations.

MS culture medium consists mainly of nutrients, vitamins, and amino acids (SILVA et al., 2017). Among plant growth regulators, auxins and cytokinins control plant developmental genes, especially those that act on cell cycle regulation, meristem induction, and rooting (DEPUYDT; HARDTKE, 2011; TANK, THAKER, 2011; NEELAKANDAN; WANG, 2012). Activated carbon is an inert compound with a high adsorption capacity for the toxic compounds released by the explant during in vitro growth (THOMAS, 2008).

Another little-studied factor is how culture medium and growth conditions can alter the biochemical responses of sweet basil explants, especially regarding antioxidant responses and enzymes that can remove free radicals (SHAHIDI; ZHONG, 2015). These responses have been investigated for medicinal plants under normal conditions, but remain unknown for in vitro explant growth (MATKOWSKI, 2008). The dynamics of explant growth under in vitro culture are different from conventional methods (WEATHERS; TOWLER; XU, 2010). Thus, plants exposed to stress show an increase in antioxidant activity and in the enzymes that remove free radicals (SHAHIDI; ZHONG, 2015). Alternatively, the growing environment could not necessarily cause stress to the plant but rather be a factor of elicitation, contributing to the production of compounds (WEATHERS; TOWLER; XU, 2010; TRETTEL et al., 2018b).

The overall objectives of this study were to investigate the effect of culture medium concentration, in combination with antioxidants and plant growth regulators, on the in vitro growth and biochemical activity of sweet basil seedlings. Therefore, our results provide new insight into how these components of the medium can alter the in vitro growth of this cultivar and how antioxidant mechanisms act to minimize the negative effects of these components.

\section{MATERIAL AND METHODS}

\section{Plant material and study site}

The experiment was conducted in the Laboratory of Molecular Biology and Plant Tissue Culture of the Universidade Paranaense. Sweet basil seeds (Ocimum basilicum L., 'Genovese') were purchased from Horticeres Sementes Ltd, Indaiatuba, SP, Brazil. The seeds were then disinfected in $2 \%$ $(\mathrm{v} / \mathrm{v})$ sodium hypochlorite solution for $15 \mathrm{~min}$ and rinsed four times in distilled water. All procedures were performed in a laminar flow chamber. 
Composition of the culture medium for sweet basil development

The disinfected seeds were inoculated in MS culture medium (MURASHIGE; SKOOG, 1962), as described in Table 1. All treatments were supplemented with $6.5 \mathrm{~g} \mathrm{~L}^{-1}$ agar (Kasvi ${ }^{\circledR}$, São José dos Pinhais, Brazil) and $30 \mathrm{~g} \mathrm{~L}^{-1}$ sucrose, and the $\mathrm{pH}$ was standardized to 5.8. The growth regulators used were 6-benzylaminopurine (BAP) and $\alpha$ naphthaleneacetic acid (NAA; Sigma Aldrich $^{\circledR}$,Darmastadt, Germany). The treatments in this bioassay were based on previous studies by Silva et al. (2017) and Trettel et al. (2018a).

Table 1. Concentration of MS medium, growth regulators and activated charcoal for genovese basil growth.

\begin{tabular}{|c|c|c|c|c|c|}
\hline & Treatment 1 & Treatment 2 & Treatment 3 & Treatment 4 & Treatment 5 \\
\hline MS medium (\%) & 100 & 70 & 70 & 100 & 100 \\
\hline Activated charcoal $\left(\mathrm{gL}^{-1}\right)$ & 0.0 & 0.0 & 3.0 & 0.0 & 3.0 \\
\hline $\mathrm{BAP}\left(\mathrm{mgL}^{-1}\right)$ & 0.0 & 0.1 & 0.1 & 0.4 & 0.4 \\
\hline NAA $\left(\mathrm{mgL}^{-1}\right)$ & 0.0 & 0.0 & 0.0 & 0.2 & 0.2 \\
\hline
\end{tabular}

After the preparation of the culture medium, the glass vials were autoclaved at $121^{\circ} \mathrm{C}$ for $20 \mathrm{~min}$. Four seeds were placed in glass vials containing 50 $\mathrm{mL}$ culture medium, which were closed with transparent plastic caps and sealed with polyvinyl chloride film. Seed inoculation was performed in an aseptic cabinet. The material was then kept in a growth chamber for 80 days at $25^{\circ} \mathrm{C}\left( \pm 2{ }^{\circ} \mathrm{C}\right)$. The photoperiod was $24 \mathrm{~h}$ (SILVA et al. 2017; TRETTEL et al. 2018a) and white fluorescent 20-W lamps (Empalux ${ }^{\circledR}$, Curitiba, Brazil) at a light intensity of $72.0 \mu \mathrm{mol} \mathrm{m} \mathrm{m}^{-2} \mathrm{~s}^{-1}$ were used.

\section{Morphological and physiological characteristics}

Seed germination rate, percentage of oxidized and abnormal seedlings, and contamination percentage were recorded every 26 days. At 80 days, the number of shoots, number of leaves, shoot length, root length, root dry mass, shoot dry mass, callus fresh mass, callus dry mass, and relative chlorophyll index were measured. The lengths of the roots and shoots were measured using digital calipers, and the dry masses of the shoots and roots were determined after drying in an oven at $65^{\circ} \mathrm{C}$ for $72 \mathrm{~h}$.

The relative chlorophyll index was measured using a chlorophyll meter (clorofiLOG ${ }^{\circledR}$ model CFL1030; Falker Automação Agrícola Ltda., Porto Alegre, RS, Brazil), with random measurements taken on the leaves in the middle third of the sweet basil seedlings.

\section{Nutrient determination}

The macro and micronutrient concentrations in the shoots and roots of the sweet basil seedlings were measured after drying in an oven at $65{ }^{\circ} \mathrm{C}$ for $72 \mathrm{~h}$. The dried samples were then finely ground in a Willey mill and sent to the Plant Tissue Laboratory of the São Paulo University for chemical analysis.
All analyses were performed in duplicate, following the methodology proposed by Malavolta, Vitti and Oliveira, (1987).

\section{Antioxidant activity using the DPPH method}

A $0.5 \mathrm{~g}$ sample of fresh sweet basil seedling leaves was macerated in liquid nitrogen to obtain the extract for measurements, as proposed by Waterhouse (2002). The method used to measure antioxidant activity was based on the scavenging activity of the 2,2-diphenyl-1-picryl-hydrazyl radical (DPPH, $60 \mu \mathrm{M}$ ), as proposed by Rufino et al. (2009). The absorbance was measured at $515 \mathrm{~nm}$ using a spectrophotometer (UV-VIS Beckman 640 B). The readings were monitored every $30 \mathrm{~min}$ to a total of four readings, while the absorbance reduction was observed until stabilization. All measurements were performed in triplicate. The results were expressed as the percentage of free radical scavenging activity ( $\%$ FRS $)$, according to the equation: $a a=\left[\left(A_{\text {control }}-\right.\right.$ $\left.\left.A_{\text {test }}\right) / A_{\text {control }}\right] \times 100$, where $a a$ is the antioxidant activity (\%), $A_{\text {control }}$ is the absorbance of the control solution, and $A_{\text {test }}$ is the absorbance of the extract samples.

\section{Enzyme activity}

The enzymatic extract was obtained by maceration of $200 \mathrm{mg}$ of fresh leaf tissue in liquid nitrogen, with the addition of $1.5 \mathrm{~mL}$ of $400 \mathrm{mM}$ potassium phosphate extraction buffer ( $\mathrm{pH} 7.8), 1.0$ $\mathrm{mM}$ EDTA, and $200 \mathrm{mM}$ ascorbic acid. The suspension was centrifuged at $12.000 \mathrm{rpm}$ for $15 \mathrm{~min}$ at $40{ }^{\circ} \mathrm{C}$ and the supernatant collected (BONACINA et al., 2017).

\section{SOD (EC 1.15.1.1)}

Superoxide dismutase (SOD, EC 1.15.1.1) activity was measured by its ability to inhibit the 
photochemical reduction of nitroblue tetrazolium, as described by Giannopolitis and Ries (1977). The absorbance of the reaction mixture was read at 560 $\mathrm{nm}$, and one unit of SOD activity (UA) was defined as the amount of enzyme required to cause $50 \%$ inhibition of the nitroblue tetrazolium photoreduction rate. The results are expressed as UA mg ${ }^{-1}$ fresh weight (FW) $\mathrm{min}^{-1}$.

\section{CAT (EC 1.11.1.6)}

Catalase (CAT, EC 1.11.1.6) activity was determined, as described by Havir and Mchale (1987), by the $\mathrm{H}_{2} \mathrm{O}_{2}$ consumption, which was monitored by reading the absorbance at $260 \mathrm{~nm}$ at the moment of $\mathrm{H}_{2} \mathrm{O}_{2}$ addition and 1 min later. The difference in absorbance was divided by the $\mathrm{H}_{2} \mathrm{O}_{2}$ molar extinction coefficient $\left(36 \mathrm{M}^{-1} \mathrm{~cm}^{-1}\right)$ (ANDERSON; JOHNSTONE; COOK, 1995). CAT activity was expressed in mmol $\mathrm{H}_{2} \mathrm{O}_{2} \mathrm{~g}^{-1} \mathrm{FW} \mathrm{min}^{-1}$.

\section{APX (EC 1.11.1.11)}

Ascorbate peroxidase (APX, EC 1.11.1.11) activity was detected according to the method described previously by Nakano and Asada (1981). The absorbance was read at $290 \mathrm{~nm} 1 \mathrm{~min}$ after $\mathrm{H}_{2} \mathrm{O}_{2}$ was added to the reaction solution. The APX activity was quantified using a molar extinction coefficient of $2.8 \mathrm{mM}^{-1} \mathrm{~cm}^{-1}$. The results were expressed in mmol ascorbate $\mathrm{g}^{-1} \mathrm{FW} \mathrm{min}^{-1}$.

All enzymes were evaluated using 96-well flat-bottomed ELISA plates. In all assays, three technical replicates and three biological replicates were used. The absorbance was read using a spectrophotometer (UV-VIS Spectra Max Plus ${ }^{\circledR}$ ) with the SoftMax Pro program, version 6.5.1.

\section{Statistical analysis}

The bioassays were installed in a completely randomized design with five replicates of six glass vials containing four basil seeds. The germination, oxidation, and abnormal seedlings were evaluated in a $3 \times 6$ factorial scheme, consisting of three evaluation times (26, 52, and 80 days) and six culture media (treatments). The morphological trait data and the enzymatic and antioxidant activity data were submitted to the Shapiro Wilk normality test. The data were then submitted to analysis of variance $(p \leq 0.05)$ and the means compared by Tukey's test $(\mathrm{p} \leq 0.05)$ using SISVAR 5.6 software (FERREIRA, 2011).

\section{RESULTS AND DISCUSSION}

The analysis of variance reported significant effects $(p \leq 0.05)$ of evaluation time and culture medium composition on the percentage of abnormal seedlings. There was no effect of the period $x$ treatment interaction on germination, oxidized seedlings, or abnormal seedlings. Only the isolated effect on abnormal seedlings was observed. Figure 1A illustrates that the highest percentage of abnormal seedlings was observed during the last evaluation at 80 days. In turn, the highest percentages of abnormal seedlings (about 20\%) were reported for the $\mathrm{T} 3\left(70 \% \mathrm{MS}\right.$ medium, $30 \mathrm{~g} \mathrm{~L}^{-1}$ sucrose, $3.0 \mathrm{~g} \mathrm{~L}^{-1}$ activated carbon, and $0.1 \mathrm{mg} \mathrm{L}^{-1}$ $\mathrm{BAP})$ and $\mathrm{T} 4\left(100 \% \mathrm{MS}\right.$ medium, $30 \mathrm{~g} \mathrm{~L}^{-1}$ sucrose, $0.4 \mathrm{~g} \mathrm{~L}^{-1} \mathrm{BAP}$, and $\left.0.2 \mathrm{~g} \mathrm{~L}^{-1} \mathrm{NAA}\right)$ culture media. The other culture media showed no significant differences, and the percentage of abnormal seedlings was approximately 10\% (Figure 1B)
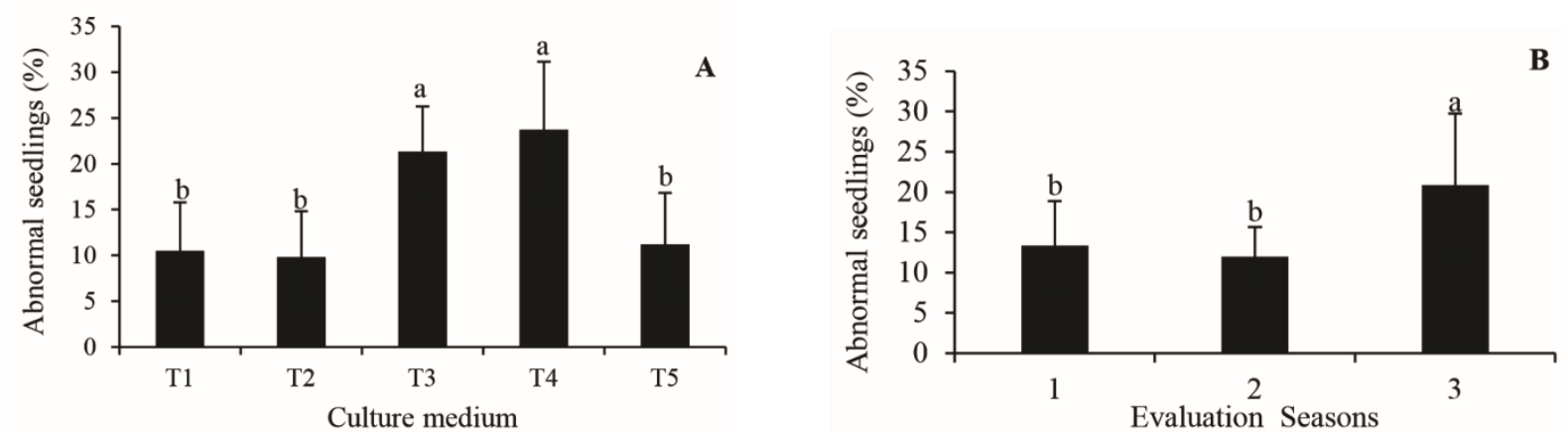

Figure 1. Isolated effect of growing season and growing medium on abnormal seedlings of Ocimum basilicum 'genovese'.

*Averages followed by the same letter in the column do not differ from each other by Tukey's test at 5\% probability. T1 - 100\% MS, absence of regulators and activated charcoal; T2 - 70\% MS $0.1 \mathrm{mg} \mathrm{L}^{-1} \mathrm{BAP}$; T3 - 70\% MS, activated charcoal 3.0 $\mathrm{g} \mathrm{L}^{-1}+0.1 \mathrm{mg} \mathrm{L}^{-1}$ BAP; T4 - 100\% MS BAP $0.4 \mathrm{mg} \mathrm{L}^{-1}+0.2 \mathrm{mg} \mathrm{L}^{-1}$ NAA; T5 - 100\% MS, activated charcoal $3.0 \mathrm{~g} \mathrm{~L}^{-1}+0.4 \mathrm{mg} \mathrm{L}^{-1} \mathrm{BAP}+0.2 \mathrm{mg} \mathrm{L}^{-1} \mathrm{NAA}$. All treatments contained $30.0 \mathrm{~g} \mathrm{~L}^{-1}$ sucrose and $6.5 \mathrm{~g} \mathrm{~L}^{-1}$ agar. Season 1 - 26 days after seed inoculation; season 2 - 52 days after seed inoculation and season 3 - 80 days after seed inoculation. 
Among the evaluation times, the percentage of abnormal plants was higher in the last evaluation, owing to the cumulative effect observed throughout the bioassay. We believe that this may be related to the accumulation in the environment of toxic compounds released by stressed plants, favoring this physiological disorder (SILVA et al., 2017).

Culture media T3 and T5 had negative effects and were limiting for sweet basil seedling growth for most of the traits measured (Table 2). Although culture medium T4 had a beneficial effect on leaf number, this culture medium impaired the production of normal basil seedlings. This can be a disadvantage during acclimatization.

At the end of the bioassay, the number of leaves and shoots and the fresh and dry mass of the shoots and roots showed significant differences, according to the culture medium used. The number of leaves was four times higher in the T4 culture medium (21.93) than in the T3 medium (5.16), representing an average increase of $77 \%$ in the number of leaves. In turn, as shown in Table 2, the number of leaves in the control treatment (T4) was $33,20 \%$ higher than that in the T1 culture medium. The fewest leaves were obtained in the T3 medium (Table 2). For Ocimum spp. plants, the number of leaves produced by the plant is very relevant. Previous studies have demonstrated that this is because the potential for essential oil production is directly related to the number of leaves on the plant, since the glands that produce the essential oil are found in this organ (ZUZARTE et al., 2010; AMARAL-BAROLI et al., 2016).

Table 2. Number of leaves (NL), number of shoots (NS), length of shoots (LS), fresh shoots (FS), dry shoots (DS), fresh root (FR), dry root (DR), fresh callus (FC), dry callus (DC) and chlorophyll (CL) of seedlings of O. basilicum 'genovese'

\begin{tabular}{llllll}
\hline Treatment & NL & NS & LS $(\mathrm{mm})$ & FS $(\mathrm{g})$ & DS $(\mathrm{g})$ \\
\hline T1 & $14.65 \pm 3.05^{\mathrm{ab}}$ & $2.0 \pm 1.82^{\mathrm{a}}$ & $52.81 \pm 6.39^{\mathrm{a}}$ & $3.65 \pm 1.43^{\mathrm{a}}$ & $0.27 \pm 0.05^{\mathrm{a}}$ \\
T2 & $8.91 \pm 7.41^{\mathrm{b}}$ & $0.0 \pm 0.00^{\mathrm{b}}$ & $49.85 \pm 40.49^{\mathrm{a}}$ & $0.91 \pm 0.79^{\mathrm{bc}}$ & $0.05 \pm 0.07^{\mathrm{b}}$ \\
T3 & $5.16 \pm 2.72^{\mathrm{b}}$ & $0.0 \pm 0.00^{\mathrm{b}}$ & $52.20 \pm 5.95^{\mathrm{a}}$ & $0.44 \pm 0.26^{\mathrm{c}}$ & $0.04 \pm 0.01^{\mathrm{b}}$ \\
T4 & $21.93 \pm 9.33^{\mathrm{a}}$ & $1.12 \pm 0.85^{\mathrm{ab}}$ & $48.39 \pm 3.61^{\mathrm{a}}$ & $2.56 \pm 0.65^{\mathrm{ab}}$ & $0.18 \pm 0.07^{\mathrm{a}}$ \\
T5 & $7.97 \pm 0.94^{\mathrm{b}}$ & $0.0 \pm 0.00^{\mathrm{b}}$ & $56.73 \pm 16.02^{\mathrm{a}}$ & $1.04 \pm 0.40^{\mathrm{bc}}$ & $0.28 \pm 0.34^{\mathrm{a}}$ \\
& FR $(\mathrm{g})$ & DR $(\mathrm{g})$ & FC $(\mathrm{g})$ & DC $(\mathrm{g})$ & CL \\
T1 & $3.18 \pm 1.03^{\mathrm{a}}$ & $0.14 \pm 0.08^{\mathrm{b}}$ & $0.00 \pm 0.00^{\mathrm{a}}$ & $0.00 \pm 0.00^{\mathrm{a}}$ & $17.05 \pm 2.72^{\mathrm{a}^{*}}$ \\
T2 & $0.95 \pm 0.66^{\mathrm{b}}$ & $0.6 \pm 0.04^{\mathrm{abc}}$ & $0.00 \pm 0.00^{\mathrm{a}}$ & $0.00 \pm 0.00^{\mathrm{a}}$ & $15.07 \pm 10.90^{\mathrm{a}}$ \\
T3 & $0.14 \pm 0.05^{\mathrm{b}}$ & $0.01 \pm 0.00^{\mathrm{c}}$ & $0.00 \pm 0.00^{\mathrm{a}}$ & $0.00 \pm 0.00^{\mathrm{a}}$ & $10.47 \pm 7.29^{\mathrm{a}}$ \\
T4 & $2.81 \pm 0.82^{\mathrm{a}}$ & $0.09 \pm 0.02^{\mathrm{ab}}$ & $1.75 \pm 2.05^{\mathrm{a}}$ & $0.10 \pm 0.11^{\mathrm{a}}$ & $20.41 \pm 1.52^{\mathrm{a}}$ \\
T5 & $0.25 \pm 0.07^{\mathrm{b}}$ & $0.23 \pm 0.01^{\mathrm{a}}$ & $0.00 \pm 0.00^{\mathrm{a}}$ & $0.00 \pm 0.00^{\mathrm{a}}$ & $13.94 \pm 13.28^{\mathrm{a}}$ \\
\hline
\end{tabular}

*Averages followed by the same letter in the column do not differ from each other by Tukey's test at $5 \%$ probability. T1 $100 \% \mathrm{MS}$, absence of regulators and activated charcoal; T2 - 70\% MS $0.1 \mathrm{mg} \mathrm{L}^{-1} \mathrm{BAP}$; T3 - 70\% MS, activated charcoal 3.0g. $\mathrm{L}^{-1}+0.1 \mathrm{mg} \mathrm{L}^{-1}$ BAP; T4 - 100\% MS BAP $0.4 \mathrm{mg} \mathrm{L}^{-1}+0.2 \mathrm{mg} \mathrm{L}^{-1} \mathrm{NAA}$; $\mathbf{T} 5$ - 100\% MS, activated charcoal $3.0 \mathrm{~g} \mathrm{~L}^{-1}$ $+0.4 \mathrm{mg} \mathrm{L}^{-1} \mathrm{BAP}+0.2 \mathrm{mg} \mathrm{L}^{-1} \mathrm{NAA}$. All treatments contained $30.0 \mathrm{~g} \mathrm{~L}^{-1}$ sucrose and $6.5 \mathrm{~g} \mathrm{~L}^{-1}$ agar.

The T3 culture medium contained $70 \% \mathrm{MS}$ growing medium and activated carbon, and lacked NAA, whereas the T4 medium contained fullstrength MS medium, lacked activated carbon, and included plant growth regulators (BAP and NAA). The higher amounts of macronutrients, especially the nitrogen associated with the plant growth regulators (Table 3), promoted an increase in the number of leaves in the T4 medium (Table 2). Studies have reported that $O$. basilicum plants are responsive to high amounts of nitrogen and plant growth regulators to promote leaf emission (SILVA et al., 2017; TRETTEL et al., 2018a). Nitrogen is a constituent of the chlorophyll molecule (GREENWAY et al., 2012) and plant growth regulators, mainly cytokinins, contribute to the expression of genes that act on the cell cycle and promote leaf emission (TANK;
THAKER, 2011; NEELAKANDAN; WANG, 2012).

The number of shoots showed little difference between the different culture media. The T1 culture medium (100\% MS medium, $30 \mathrm{~g} \mathrm{~L}^{-1}$ sucrose, and an absence of activated carbon, BAP, and NAA) promoted a higher number of shoots than the other media, except T4 (Table 2). The T2, T3, and T5 media did not favor an increase in the number of shoots in sweet basil plants (Table 2). The material propagated from seeds may have limited shoot emission capacity, but this seems to be a characteristic of the genus Ocimum, which has a lower shoot emission rate than other species. For example, studies with plants of the Zingiberaceae family have reported that these plants have a high ability to emit shoots (MELLO; AMARAL; MELO, 
2000; YUSUF; ANNUAR; KHALID, 2011; JALA, 2012). The low shoot emission capacity of plants of this genus may be caused by genetic factors. We believe that the genotype is the main factor involved. Therefore, the use of culture media with other rates of plant growth regulators may be able to stimulate the production of more shoots.

The fresh mass of shoots was higher in culture medium $\mathrm{T} 1$, followed by medium $\mathrm{T} 4$. The $\mathrm{T} 1$ medium resulted in $30 \%$ and $12 \%$ increases in the shoot fresh mass compared to the T4 culture medium (Table 2). However, the root dry matter of T1, T4, and T5 were statistically equal. Regarding the root system, the fresh root mass seemed to be greater in the T1 and T4 treatments, but no statistical difference was observed for either. The highest average dry root mass was observed in T5 (Table 2). The amount of matter produced by a plant is usually associated with the amount of mitosis and cell sizes. Plant growth regulators play a fundamental role in this regard, especially cytokinins, which act directly on the cell cycle (TANK; THAKER, 2011). However, in this study, the addition of plant growth regulators did not result in the expected plant growth gain, since the $\mathrm{T} 1$ medium that had no exogenous regulators had the highest plant matter accumulation.

Seeds contain a small amount of plant growth regulators, which should be sufficient for the initial maintenance of signaling activities for some plant growth characteristics. Part of the organogenesis process is linked to the concentration and ability of the growth regulator to bind to its receptor on the cell membrane (DEPUYDT; HARDTKE, 2011). It is therefore important to test the concentration of plant growth regulators. If the amount exceeds what can be metabolized by the plant cell, the effect on the seedling is reversed, as the surplus becomes toxic to the plant cell (MOTTE et al., 2014). Thus, seedling growth is compromised. Moreover, the growth regulator may contribute to the expression of other genes that would not be needed at that time.
Regarding the root growth of $O$. basilicum seedlings and other species of the Lamiaceae family, it has been verified that a reduction in nutrient concentration in the culture medium favored the growth and mass production of the root system. For example, the 'Genovese' and 'Basilicão Roxo' basil cultivars exposed to a $70-80 \%$ saline concentration showed an increase in root length and mass (SILVA et al., 2017; TRETTEL et al., 2018a). For other species of the Lamiaceae family, a reduction of up to $50 \%$ in salts favored root system growth (FADEL et al., 2010; SWAMY; MOHANTY; ANURADHA, 2014).

These results are mainly associated with the fact that the roots are most commonly affected, as they are the first to make direct contact with the growth medium in vitro (FADEL et al., 2010). Also, the imbalance and interactions between macro and micronutrients in the culture medium (antagonism and synergism) can be a factor that influences root growth (SILVA; TREVIZAM, 2015). This was not observed in this bioassay, where the root system grew better in the M1 and M5 media, which both contain full-strength MS growth medium (Table 2).

Our results also demonstrate that the relative chlorophyll index, shoot length, and callus dry and fresh masses were not influenced by in vitro growth media $(\mathrm{p}>0.05)$ (Table 2).

Macro and micronutrient evaluation showed that, in the shoots $\left(54.42 \mathrm{~g} \mathrm{~kg}^{-1} \mathrm{DW}\right)$ and roots (38.75 $\left.\mathrm{g} \mathrm{kg}^{-1} \mathrm{DW}\right)$, the T4 culture medium resulted in higher nitrogen concentrations in $O$. basilicum seedlings. (Table 3 ). The shoots had a higher amount of $\mathrm{N}$ than the roots, at approximately $10 \mathrm{~g} \mathrm{~kg}^{-1} \mathrm{DW}$. This is generally expected owing to the increased need for this nutrient for the formation of chlorophyll molecules. The $\mathrm{N}$ concentration in the shoots and roots of the sweet basil seedlings in the T3 and T5 culture media, respectively, could not be measured (Table 3 ).

Table 3. Macro and micronutrient constituents, N (Nitrogen), Cu (Copper) Zn (zinc), S (Shoot), R (Root) of $O$. basilicum 'genovese' in function of different MS medium formulations.

\begin{tabular}{lllllll}
\hline & $\mathrm{g} \mathrm{Kg}^{-1}$ & & $\mathrm{mg} \mathrm{kg}^{-1}$ & & $\mathrm{mg} \mathrm{kg}^{-1}$ & \\
\cline { 2 - 7 } Treatments & $\mathrm{N}$ & $\mathrm{Cu}$ & & $\mathrm{Zn}$ & \\
& $\mathrm{S}$ & $\mathrm{R}$ & $\mathrm{S}$ & $\mathrm{R}$ & $\mathrm{S}$ & $\mathrm{R}$ \\
$\mathrm{T} 1$ & $40.31 \pm 0.52$ & $37.39 \pm 4.55$ & $10.00 \pm 0.00$ & $11.50 \pm 2.12$ & $81.00 \pm 4.24$ & $83.00 \pm 2.82$ \\
$\mathrm{~T} 2$ & $42.06 \pm 0.00$ & $30.55 \pm 0.00$ & $10.50 \pm 2.12$ & $10.50 \pm 2.12$ & $74.00 \pm 16.97$ & $60.00 \pm 2.82$ \\
$\mathrm{~T} 3$ & - & $27.90 \pm 0.00$ & $10.50 \pm 2.12$ & - & $60.00 \pm 0.00$ & - \\
$\mathrm{T} 4$ & $54.42 \pm 2.10$ & $38.75 \pm 0.71$ & $15.00 \pm 4.24$ & $9.50 \pm 0.71$ & $89.50 \pm 2.12$ & $53.50 \pm 0.70$ \\
$\mathrm{~T} 5$ & $40.47 \pm 2.07$ & - & $10.00 \pm 2.83$ & $17.00 \pm 0.0$ & $68.00 \pm 15.55$ & $55.00 \pm 2.82$ \\
\hline
\end{tabular}

T1 - 100\% MS, absence of regulators and activated charcoal; T2 - 70\% MS 0.1 $\mathrm{mg} \mathrm{L}^{-1}$ BAP; T3 - 70\% MS, activated charcoal 3.0g. $\mathrm{L}^{-1}+0.1 \mathrm{mg} \mathrm{L}^{-1}$ BAP; T4 - 100\% MS BAP $0.4 \mathrm{mg} \mathrm{L}^{-1}+0.2 \mathrm{mg} \mathrm{L}^{-1} \mathrm{NAA} ; \mathbf{T 5}-100 \% \mathrm{MS}$, activated charcoal $3.0 \mathrm{~g} \mathrm{~L}^{-1}+0.4 \mathrm{mg} \mathrm{L}^{-1} \mathrm{BAP}+0.2 \mathrm{mg} \mathrm{L}^{-1} \mathrm{NAA}$. All treatments contained $30.0 \mathrm{~g} \mathrm{~L}^{-1}$ sucrose and $6.5 \mathrm{~g} \mathrm{~L}^{-1}$ agar. 
Regarding $\mathrm{Cu}$ and $\mathrm{Zn}$ concentrations, Thomas (2008) reported that activated carbon could adsorb these micronutrients in the culture medium, thus limiting their availability to seedlings. This was an initial hypothesis to be tested in this bioassay. The $\mathrm{Cu}$ concentration in the shoots was similar in all culture media except the T4 medium $\left(15.0 \mathrm{mg} \mathrm{kg}^{-1}\right.$ DW), which contained no activated charcoal (Table $3)$. In the roots, the highest $\mathrm{Cu}$ concentration was found in the $\mathrm{T} 5$ medium $\left(17.0 \mathrm{mg} \mathrm{kg} \mathrm{mW}^{-1} \mathrm{DW}\right.$, which contained $3.0 \mathrm{~g} \mathrm{~L}^{-1}$ activated carbon, and the lowest $\mathrm{Cu}$ concentration in the T4 medium $\left(9.50 \mathrm{mg} \mathrm{kg}^{-1}\right)$. The $\mathrm{Cu}$ concentration in the $\mathrm{T} 3$ culture medium could not be measured.

Therefore, this hypothesis was partially supported in the shoots, which presented more leaves. The increased availability of $\mathrm{Cu}$ in the seedlings may also have favored this characteristic. Results from other bioassays of Ocimum plants showed that the addition of $\mathrm{Cu}$ to the culture medium $(25 \mu \mathrm{M})$ promoted less abnormal plants and higher leaf increments (TRETTEL et al., 2017; TRETTEL et al., 2018b). These observations indicate a beneficial response to the addition of $\mathrm{Cu}$ to $O$. basilicum seedlings. The hypothesis suggested by these authors was that this nutrient favored the production of phenylpropanoids, which are the precursors of lignin (LIU, 2012; BAXTER; STEWART, 2013). Thus, our results suggest an increase in the number of leaves in the sweet basil seedlings.

In contrast, the culture medium containing activated carbon was the one with the highest $\mathrm{Cu}$ concentration in the root system of the seedlings. This effect was also verified for some other Ocimum species. Trettel et al. (2018b) observed this result for the "asilicão verde" basil cultivar, and associated it with a $\mathrm{Cu}$ economy mechanism. Llorens, Arola and Bladé (2000) reported that when there is an excess of $\mathrm{Cu}$, the plant initiates an immobilization mechanism that increases the concentration of this metal, especially in the plant roots. Therefore, the response in the assimilation of this metal is not only concerns the presence or absence of charcoal in the culture medium, but also the genotype and type of organ analyzed (roots or shoots).

Results from other bioassays have shown that $\mathrm{Zn}$ is a more readily absorbed micronutrient in sweet basil seedlings than $\mathrm{Cu}$ (SILVA et al., 2017). For this bioassay, the results showed that the highest values $\left(89.50 \mathrm{mg} \mathrm{kg}^{-1}\right)$ were observed in the shoots of seedlings that grew in the $\mathrm{T} 4$ culture medium, followed by those in the T1 medium $\left(81.00 \mathrm{mg} \mathrm{kg}^{-1}\right)$. Seedlings grown on M1 had higher $\mathrm{Zn}$ concentrations in their roots $\left(83.00 \mathrm{mg} \mathrm{kg}^{-1}\right)$. In the other culture media, the values for this micronutrient were similar.

For $\mathrm{Zn}$, the hypothesis suggested by Thomas (2008) was confirmed in the shoots, since the culture media that did not contain activated carbon resulted in higher $\mathrm{Zn}$ absorption by the seedlings. The response of the root system was similar to that observed in the shoots.

Among medicinal plants, sweet basil has significant antioxidant properties (JAVANMARDI et al., 2003; TENORE et al., 2017). This is because of their chemical composition, which includes phenylpropanoids, such as methyl eugenol and eugenol (TRETTEL et al., 2017; TRETTEL et al., $2018 \mathrm{~b}$ ), and other phenolic acids, such as rosmarinic acid derived from caffeic acid (KIFERLE; MAGGINI; PARDOSSI, 2013; PAGANO et al., 2018).

The DPPH method is relevant for evaluating antioxidant activity since DPPH acts as a radical that is oxidized by phenolic compounds. In this bioassay, the T5 culture medium (100\% MS medium, $30 \mathrm{~g} \mathrm{~L}^{-1}$ sucrose, $30 \mathrm{~g} \mathrm{~L}^{-1}$ activated carbon, $0.4 \mathrm{mg} \mathrm{L}^{-1} \mathrm{BAP}$, and $0.2 \mathrm{mg} \mathrm{L}^{-1} \mathrm{NAA}$ ) had higher antioxidant activity $(6.92 \%)$, followed by the M2 culture medium (4.69\%) (Table 4). The lowest antioxidant activity was obtained in the T4 medium $(0.08 \%)$, which was also the treatment that had the highest number of $O$ basilicum seedling leaves (Table 2 ).

Table 4. Antioxidant activity obtained from fresh genovese basil leaves grown in vitro.

\begin{tabular}{cccccc}
\hline Treatments & T1 & T2 & T3 & T4 & T5 \\
\hline $\begin{array}{l}\text { Antioxidant } \\
\text { activity (\%) }\end{array}$ & $1.94 \pm 0.25^{\mathrm{bc}^{*}}$ & $4.69 \pm 0.80^{\mathrm{ab}}$ & $1.86 \pm 0.17^{\mathrm{bc}}$ & $0.08 \pm 0.01^{\mathrm{c}}$ & $6.92 \pm 0.91^{\mathrm{a}}$ \\
\hline
\end{tabular}

*Averages followed by the same letter in the column do not differ from each other by Tukey's test at 5\% probability. T1 - 100\% MS, absence of regulators and activated charcoal; T2 - 70\% MS 0.1mg L $\mathrm{m}^{-1} \mathrm{BAP}$; T3 $70 \% \mathrm{MS}$, activated charcoal $3.0 \mathrm{~g} \mathrm{~L}^{-1}+0.1 \mathrm{mg} \mathrm{L}^{-1}$ BAP; T4 - 100\% MS BAP $0.4 \mathrm{mg} . \mathrm{L}^{-1}+0.2 \mathrm{mg} \mathrm{L}^{-1} \mathrm{NAA}$; T5 $100 \% \mathrm{MS}$, activated charcoal $3.0 \mathrm{~g} \mathrm{~L}^{-1}+0.4 \mathrm{mg} \mathrm{L}^{-1} \mathrm{BAP}+0.2 \mathrm{mg} \mathrm{L}^{-1} \mathrm{NAA}$. All treatments contained $30.0 \mathrm{~g} \mathrm{~L}^{-1}$ sucrose and $6.5 \mathrm{~g} \mathrm{~L}^{-1}$ agar.

This result clearly indicates that the $\mathrm{T} 4$ culture medium produces less stress on the seedlings, because antioxidant activity in plants tends to increase under stressful conditions. This is a biochemical response of plants to mitigate cell and physiological damage (NGUYEN; KWEE, E. M.; NIEMEYER, 2010). One of the mechanisms of plant defense is to increase the production of compounds that block free radicals, as well as some other phenolic compounds that have this oxidative stress 
function (BARBOSA et al., 2014). A plant grown in vitro can respond with its antioxidant capacity in two ways. Either it can increase the production of phenolic compounds owing to stressful conditions (MATKOWSKI, 2008), or the production of these compounds can be favored not owing to stress, but to mechanisms of elicitation (ALVAREZ, 2014; TRETTEL et al., 2018b). Medicinal plants are highly favorable for this process (ALVAREZ, 2014).

Free radical scavenging enzymes are essential mechanisms that plants use to mitigate free radical damage (BARBOSA et al., 2014). Among these enzymes, three have been widely studied because of their importance, APX, CAT, and SOD. When the level of oxygen or nitrogen free radicals is high in plants, these enzymes promote cell cleansing with the aim of neutralizing damage to lipids, proteins, and nucleic acids (BARBOSA et al., 2014;
SHAHIDI, ZHONG, 2015). There is a lack of studies on basil grown in vitro. Understanding how plants mitigate oxidative damage in different culture media contributes to improving micropropagation protocols and plant development in vitro.

For free radical scavenging enzymes, a variety of activities were observed according to the enzyme analyzed. APX had higher activity in the T3 culture medium $(0.3 \mathrm{mM})$. In the other culture media, there was a decrease from $0.15 \mathrm{mM}$ (Figure $2 \mathrm{~A})$. For CAT, the T3 culture medium also showed higher activity $(2.0 \mathrm{mM})$ (Figure $2 \mathrm{~B})$. Among the three enzymes evaluated, SOD had the highest activity value and showed the largest differences between the culture media. The M3 culture medium had the highest activity $(200 \mathrm{U})$, followed by the T4 medium (125 U), while the lowest activity was observed in the M2 medium (50 U) (Figure 2C).
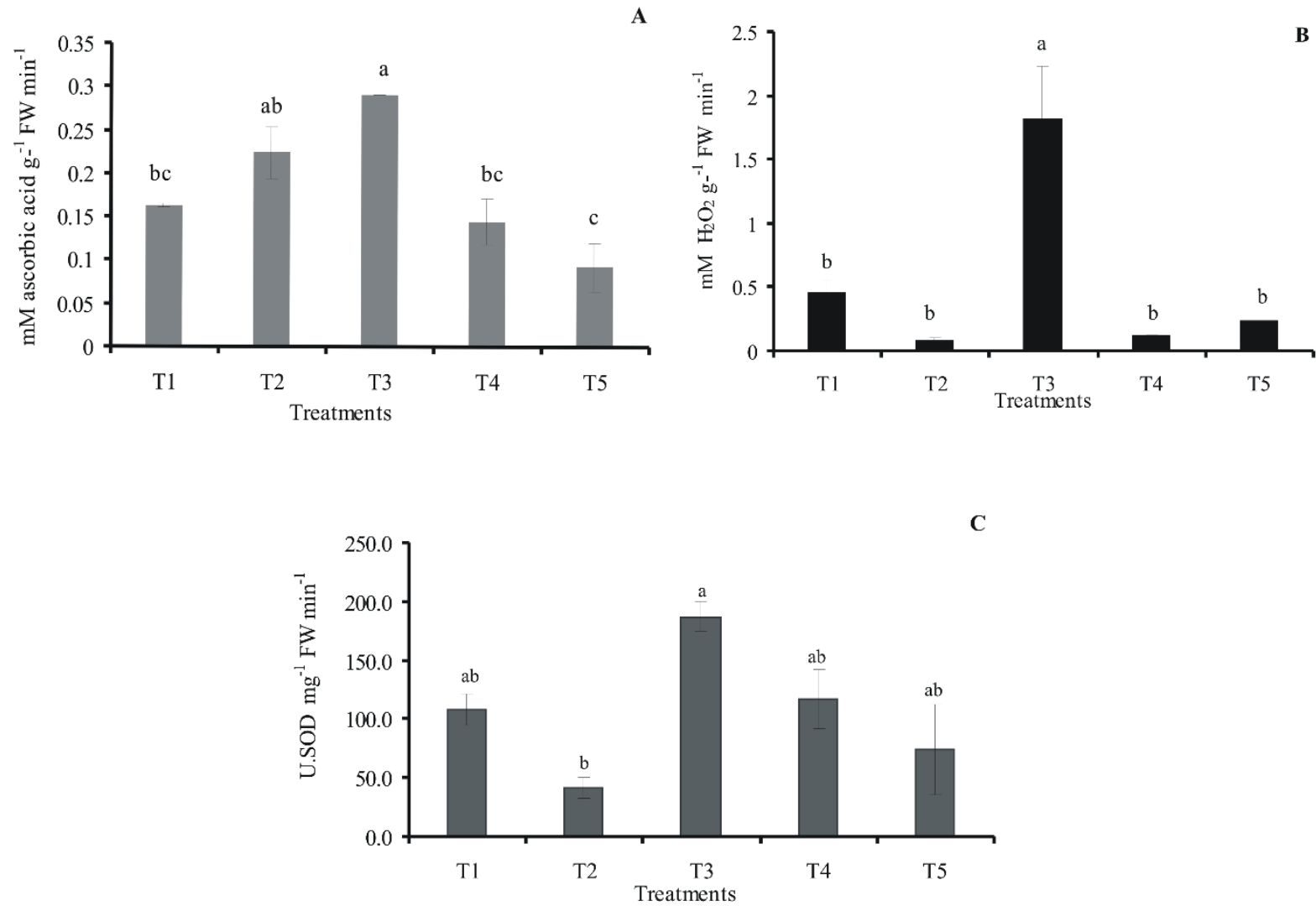

Figure 2. Enzymatic activity of ascorbid peroxidase APX (A), CAT catalase (B) and superoxide dismutase SOD (C) obtained from different culture medium formulations.

*Averages followed by the same letter in the column do not differ from each other by Tukey's test at $5 \%$ probability. T1 - 100\% MS, absence of regulators and activated charcoal; T2 - 70\% MS 0.1mg L $\mathrm{L}^{-1}$ BAP; T3 - 70\% MS, activated

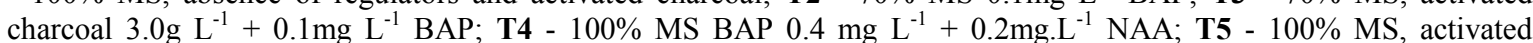
charcoal $3.0 \mathrm{~g} \mathrm{~L}^{-1}+0.4 \mathrm{mg} \mathrm{L}^{-1} \mathrm{BAP}+0.2 \mathrm{mg} \mathrm{L}^{-1} \mathrm{NAA}$. All treatments contained $30.0 \mathrm{gL}^{-1}$ sucrose and $6.5 \mathrm{~g} \mathrm{~L}^{-1}$ agar.

Hence, in our study, the three enzymes analyzed showed higher activity in the T3 culture medium, which, together with the T5 medium, promoted inadequate conditions for the germination and growth of sweet basil seedlings.

It may be that the results observed in this study are also related to other mechanisms that plants use to mitigate oxidative damage. The plant cell has at least two defense mechanisms: enzymatic defense, such as the studied enzymes (SHAHIDI; ZHONG, 2015; BARBOSA et al., 2014), and nonenzymatic defense, which can be subdivided into 
two classes. These are the secondary metabolism compounds, such as phenols (KWEE; NIEMEYER, 2011; FLANIGAN, NIEMEYER, 2014), and vitamins, such as ascorbic acid and vitamin E (SIES; STAHL, 1995).

When a plant needs to perform free radical scavenging, one of these mechanisms will work the most efficiently and the plant can change its approach as needed. For example, the results from the 'Genovese' basil cultivar showed that the T3 culture medium caused greater enzymatic metabolic changes, while the T5 medium resulted in increased production of compounds, possibly phenolic compounds, overshadowing the enzymatic mechanism.

For Ocimum species, the results observed for in vitro growth indicate differences between cultivars (SILVA et al., 2017; TRETTEL et al., 2018a; TRETTEL et al., 2018b). There is a tendency among researchers to replicate in vitro culture medium for species in the same family or for similar plants. The results reported here and compared with other studies show that this practice should not be recommended. According to Neelakandan and Wang (2012), the morphological and physiological responses observed in plant growth are the product of the interaction between the culture medium, growth conditions (light, photoperiod, and temperature), and genotype. Although cultivars usually have very similar genotypes, some differences modify their phenotypes.

The results of this research showed an initial culture medium formulation for the 'Genovese' cultivar, which was previously nonexistent. Therefore, new stages of in vitro culture should be established, such as the improvement and stimulation of shoots and the adaptation of conventional procedures for cultivation in bioreactors. This can improve the multiplication rate of this cultivar. The seedlings can be acclimatized or be used for the medicinal and pharmaceutical industries.

\section{CONCLUSIONS}

We conclude that most of the characteristics we evaluated in this study, with emphasis on the number of leaves, the dry mass of the shoots, and the fresh mass of the roots, were favored in the T1 $(100 \% \mathrm{MS}$, absence of regulators and activated charcoal) and T4 (100\% MS, BAP $0.4 \mathrm{mg} \mathrm{L}^{-1}+0.2$ $\mathrm{mg} \mathrm{\textrm {L } ^ { - 1 } )}$ treatments. These media are therefore recommended for in vitro cultivation of the 'Genovese' cultivar.

The antioxidant activity was high in the seedlings grown in the culture medium composed of $100 \% \mathrm{MS}$ medium $+3.0 \mathrm{~g} \mathrm{~L}^{-1}$ activated carbon +0.4 $\mathrm{mg} \mathrm{L} \mathrm{L}^{-1} \mathrm{BAP}+0.2 \mathrm{mg} \mathrm{L}^{-1} \mathrm{NAA}$ (T5) and that composed of $70 \% \mathrm{MS}$ medium $+3.0 \mathrm{~g} \mathrm{~L}^{-1}$ activated carbon $+0.1 \mathrm{mg} \mathrm{L}^{-1}$ BAP (T3), which limited the growth rates of the sweet basil seedlings.

\section{ACKNOWLEDGMENTS}

We would like to thank the Coordenação de Aperfeiçoamento de Pessoal de Nivel Superior (CAPES) $\mathrm{n}^{\circ} 001$ and Conselho Nacional de Desenvolvimento Científico e Tecnológico (CNPq) for funding this work. And Universidade Paranaense (UNIPAR) for financial support.

\section{REFERENCES}

ALVAREZ, M. A. Plant biotechnology for health: from secondary metabolites to molecular Farming. Buenos Aires: Springer, 2014. 161 p.

AMARAL-BAROLI, A. et al. Variability in essential oil composition produced by micropropagated (in vitro), acclimated (ex vitro) and in-field plants of Ocimum basilicum (Lamiaceae). Industrial Crops and Products, 86: 180-185, 2016.

ANDERSON, J. W.; JOHNSTONE, B. M.; COOK, N. Meta-analysis of the effects of soy protein intake on serum lipids. New England Journal of Medicine, 333: 276-282, 1995.

BARBOSA, M. R. et al. Geração e desintoxicação enzimática de espécies reativas de oxigênio em plantas. Ciência Rural, 44: 453-460, 2014.

BAXTER, H.; STEWART, J. C. Effects of altered lignin biosynthesis on phenylpropanoid metabolism and plant stress. Biofuels, 4: 635-650, 2013.

BONACINA, C. et al. Changes in growth, oxidative metabolism and essential oil composition of lemon balm ('Melissa officinalis' L.) subjected to salt stress. Australian Journal of Crop Science, 11: 16651674, 2017.

DEPUYDT, S.; HARDTKE, C. S. Hormone signalling crosstalk in plant growth regulation. Current Biology, 21: 365-373, 2011.

FADEL, D. et al. Effect of different strength of medium on organogenesis, phenolic accumulation and antioxidant activity of spearmint (Mentha spicata L.). The Open Horticulture Journal, 3: 31352010.

FERREIRA, D. F. Sisvar: A computer statical analysis system. Ciência e Agrotecnologia, 35: 1039-1042, 2011. 
FLANIGAN, P. M., NIEMEYER, E. D. Effect of cultivar on phenolic levels, anthocyanin composition, and antioxidant properties in purple basil (Ocimum basilicum L.). Food Chemistry, 164: 518-526, 2014.

GIANNOPOLITIS, I.; RIES, S. K. Superoxide dismutases: I. Occurrence in higher plants. Plant Physiology, 59: 309-314, 1977.

GREENWAY, M. B. et al. A nutrient medium for diverse applications and tissue growth of plant species in vitro.In Vitro Cellular \& Developmental Biology-Plant, 48: 403-410, 2012.

HAVIR, E. A.; MCHALE, N. A. Biochemical and developmental characterization of multiple forms of catalase in tobacco leaves. Plant Physiololgy, 84: 450-455, 1987.

JALA, A. Effects of NAA BA and sucrose on shoot induction and rapid micropropagation by trimming shoot of Curcuma longa L. Thammasat International Journal of Science and Technology, 17: 54-60, 2012.

JAVANMARDI, J. et al. Antioxidant activity and total phenolic content of Iranian Ocimum accessions. Food Chemistry, 83: 547-550, 2003.

KIFERLE, C.; MAGGINI, R.; PARDOSSI, A. Influence of nitrogen nutrition on growth and accumulation of rosmarinic acid in sweet basil (Ocimum basilicum L.) grown in hydroponic culture. Australian Journal of Crop Science, 7: 321-327, 2013.

KWEE, E. M.; NIEMEYER, E. D. Variations in phenolic composition and antioxidant properties among 15 basil (Ocimum basilicum L.) cultivars. Food Chemistry, 128: 1044-1050, 2011.

LIBER, Z. et al. Chemical characterization and genetic relationships among Ocimum basilicum L. cultivars. Chemistry \& Biodiversity, 11: 19781989, 2011.

LIU, C. J. Deciphering the enigma of lignification: precursor transport, oxidation, and the topochemistry of lignin assembly. Molecular Plant, 5: 304-317, 2012.

LLORENS, N.; AROLA, L.; BLADÉ, C. et al. Effects of copper exposure upon nitrogen metabolism in tissue cultured Vitis vinifera. Plant Science, 160: 159-163, 2000.

MALAVOLTA, E. VITTI, G. C.; OLIVEIRA, S. A. Avaliação do estado nutricional das plantas: princípios e aplicações. 2. ed. Piracicaba, SP:
Potáfos, 1987. 319 p.

MAROTTI, M.; PICCAGLIA, R.; GIOVANELLI, E. Differences in essential oil composition of basil (Ocimum basilicum L.) Italian cultivars related to morphological characteristics. Journal of Agricultural and Food Chemistry, 44: 3926-3929, 1996.

MATKOWSKI, A. Plant in vitro culture for the production of antioxidants-a review. Biotechnology Advances, 26: 548-560, 2008.

MELLO, M. O.; AMARAL, A. F.; MELO, M. Quantifying the micropropagation of Curcuma zedoaria Roscoe. Scientia Agricola, 57: 703-707, 2000

MOTTE, $\mathrm{H}$. et al. The molecular path to in vitro shoot regeneration. Biotechnology Advances, 32: $107-121,2014$

MURASHIGE, T.; SKOOG, F. A revised medium for rapid growth and bio assays with tobacco tissue cultures. Physiologia Plantarum, 15: 473-497, 1962.

NAKANO, Y.; ASADA, K. Hydrogen peroxide is scavenged by ascorbate specific peroxidase in spinach chloroplasts. Plant and Cell Physiology, 22: 867-880, 1981

NEELAKANDAN， A. K.; WANG，K. Recent progress in the understanding of tissue cultureinduced genome level changes in plants and potential applications. Plant Cell Reports, 31: 597-620, 2012.

NGUYEN, P. M.; KWEE, E. M.; NIEMEYER, E. D. Potassium rate alters the antioxidant capacity and phenolic concentration of basil (Ocimum basilicum L.) leaves. Food Chemistry, 123:1235-1241, 2010.

PAGANO, I. et al. Selective extraction of high $\square$ value phenolic compounds from distillation wastewater of basil (Ocimum basilicum L.) by pressurized liquid extraction. Electrophoresis, 39: 1884-1891, 2018.

RUFINO, M. S. M. et al. Free radical scavenging behavior of some North-east Brazilian fruits in DPPH system. Food Chemistry, 114: 693-695, 2009.

SHAHIDI, F.; ZHONG, Y. Measurement of antioxidant activity. Journal of Functional Foods, 18: 757-781, 2015

SIES, H; STAHL, W. Vitamins E and C, a-carotene, and other carotenoids as antioxidants. The American Journal of Clinical Nutrition, 62: 1315- 
1321,1995 .

SILVA, F. J. et al. 'In vitro'cultivation of purple basil 'Ocimum basilicum'L. 'red rubin' at different levels of salts, charcoal, sucrose and potassium iodine. Australian Journal of Crop Science, 11: 11371145, 2017.

SILVA, M. L. S.; TREVIZAM, A. R. Interações iônicas e seus efeitos na nutrição de plantas. Informe Agronômico, 1:10-16, 2015.

SWAMY, M. K.; MOHANTY, S. K.; ANURADHA, $M$. The effect of plant growth regulators and natural supplements on in vitro propagation of Pogostemon cablin Benth. Journal of Crop Science and Biotechnology, 17: 71-78, 2014.

TANK, J. G.; THAKER, V. S. Cyclin dependent kinases and their role in regulation of plant cell cycle. Biologia Plantarum, 55: 201-212, 2011.

TENORE, G. C. et al. Antioxidant and antimicrobial properties of traditional green and purple "Napoletano" basil cultivars (Ocimum basilicum L.) from Campania region (Italy). Natural product research, 31: 2067-2071, 2017.

THOMAS, T. D. The role of activated charcoal in plant tissue culture. Biotechnology Advanced, 26:.618-631, 2008.

TRETTEL, J. R. et al. In vitro growth of genovese basil in response to different concentrations of salts and interaction of sucrose and activated carbon. Journal of Agricultural Science, 10:1-11, $2018 \mathrm{a}$.

TRETTEL, J. R. et al. Effects of copper sulfate $\left(\mathrm{CuSO}_{4}\right)$ elicitation on the chemical constitution of volatile compounds and the in vitro development of Basil. Scientia Horticulturae, 234: 19-26, 2018 b.

TRETTEL, J. R. et al. Volatile essential oil chemical composition of basil (Ocimum basilicum L. "Green") cultivated in a greenhouse and micropropagated on a culture medium containing copper sulfate. In Vitro Cellular \& Developmental Biology - Plant, 53: 631 $-640,2017$.

WATERHOUSE, A. L. Wine phenolics. Annals of the New York Academy of Sciences. 957: 21-36, 2002.

WEATHERS, P. J.; TOWLER, M. J.; XU, J. Bench to batch: advances in plant cell culture for producing useful products. Applied Microbiology and Biotechnology, 85: 1339-1351, 2010.
Rapid micropropagation of Boesenbergia rotunda (L.) Mansf. Kulturpfl. (a valuable medicinal plant) from shoot bud explants. African Journal of Biotechnology, 10: 1194-1199, 2011.

ZUZARTE, M. R. et al. Trichomes, essential oils and in vitro propagation of Lavandula pedunculata (Lamiaceae). Industrial Crops and Products, 32: 580-587, 2010

YUSUF, N. A.; ANNUAR, M. S.; KHALID, N.

This work is licensed under a Creative Commons Attribution-CC-BY https://creativecommons.org/licenses/by/4.0 